\title{
B cells mediate chronic allograft rejection independently of antibody production
}

\author{
Qiang Zeng,, ${ }^{1,2}$ Yue-Harn Ng,1,3,4 Tripti Singh,1,3 Ke Jiang,, 1,2,5 Khaleefathullah A. Sheriff,1,2 \\ Renee Ippolito, ${ }^{1,2}$ Salwa Zahalka, ${ }^{3}$ Qi Li, 1,2 Parmjeet Randhawa, 1,6 Rosemary A. Hoffman, 1,2,7 \\ Balathiripurasundari Ramaswami, ${ }^{1,2}$ Frances E. Lund, ${ }^{8}$ and Geetha Chalasani $1,3,7,9$

\begin{abstract}
${ }^{1}$ Thomas E. Starzl Transplantation Institute, 2Department of Surgery, and ${ }^{3}$ Department of Medicine (Renal-Electrolyte), University of Pittsburgh School of Medicine, Pittsburgh, Pennsylvania, USA. ${ }^{4}$ Department of Medicine (Nephrology), National University Hospital, Singapore. ${ }^{5}$ Department of Thoracic Surgery, Union Hospital, Tongji Medical College, Wuhan, People's Republic of China. ${ }^{6}$ Department of Pathology and 7Department of Immunology, University of Pittsburgh School of Medicine, Pittsburgh, Pennsylvania, USA. ${ }^{8}$ Department of Microbiology, University of Alabama at Birmingham, Birmingham, Alabama, USA. 9Department of Medicine (Nephrology), VA Pittsburgh Healthcare System, Pittsburgh, Pennsylvania, USA.
\end{abstract}

\begin{abstract}
Chronic rejection is the primary cause of long-term failure of transplanted organs and is often viewed as an antibody-dependent process. Chronic rejection, however, is also observed in mice and humans with no detectable circulating alloantibodies, suggesting that antibody-independent pathways may also contribute to pathogenesis of transplant rejection. Here, we have provided direct evidence that chronic rejection of vascularized heart allografts occurs in the complete absence of antibodies, but requires the presence of $B$ cells. Mice that were deficient for antibodies but not B cells experienced the same chronic allograft vasculopathy (CAV), which is a pathognomonic feature of chronic rejection, as WT mice; however, mice that were deficient for both $B$ cells and antibodies were protected from CAV. B cells contributed to CAV by supporting splenic lymphoid architecture, $T$ cell cytokine production, and infiltration of $T$ cells into graft vessels. In chimeric mice, in which $B$ cells were present but could not present antigen, both $T$ cell responses and CAV were markedly reduced. These findings establish that chronic rejection can occur in the complete absence of antibodies and that $B$ cells contribute to this process by supporting $T$ cell responses through antigen presentation and maintenance of lymphoid architecture.
\end{abstract}

\section{Introduction}

Chronic rejection causing late allograft failure remains a clinical challenge despite advances in immunosuppression (1). A characteristic feature of chronic rejection is concentric intimal hyperplasia, termed chronic allograft vasculopathy (CAV), which is not only prominent in heart allografts, but is also prevalent in kidney, liver, and pancreas allografts (2). Antibodies are considered important for pathogenesis of CAV, since donor-specific antibodies (DSA) predate chronic rejection in transplant recipients (3-5) and transfer of donor-reactive antibodies to T and B cell-deficient mice results in CAV $(6,7)$. Nevertheless, a substantial number $(30 \%-50 \%)$ of kidney and heart allograft recipients experiencing chronic rejection do not have detectable circulating DSA or complement deposits in the graft $(3,5,8)$. Also, minor antigenmismatched heart transplants in mice do not elicit donor-reactive antibodies, yet the mice develop significant $\mathrm{CAV}$, suggesting that other mediators of chronic rejection exist (7). Although some studies have shown that NK cells, T cells, macrophages, IFN- $\gamma$, and TNFR contribute to CAV (9-13), the concomitant potential effects of antibodies and/or B cells were not excluded in these studies. In addition to producing antibodies, B cells influence $\mathrm{T}$ cell responses by mechanisms such as antigen presentation, cytokine production, costimulation, and organization of splenic lymphoid architecture required for productive immunity (14-19). Here, we investigated whether CAV occurs in the complete absence of antibodies and whether B cells contribute to its pathogenesis beyond functioning as antibody-producing cells.

Conflict of interest: The authors have declared that no conflict of interest exists. Citation for this article: J Clin Invest. 2014;124(3):1052-1056. doi:10.1172/JCI70084.

\section{Results and Discussion}

$B$ cells are sufficient for CAV in the absence of antibodies. To study the roles of $\mathrm{B}$ cells and antibodies in the pathogenesis of CAV, a heterotopic allogeneic heart transplantation model was used in which acute rejection was inhibited by treating recipients with costimulation blockade (CTLA4Ig and anti-CD40L) (20). Mice that were either deficient in both B cells and antibodies $(\mu \mathrm{MT})$ or antibodies

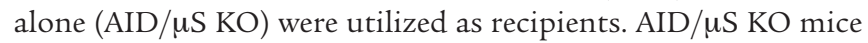
lack the genes encoding both secretory $\operatorname{IgM}$ ( $\mu$ s; secretory Ighm) and activation-induced deaminase (AID; Aicda), and their B cells cannot undergo affinity maturation or secrete antibodies of any isotype (21). $\mu \mathrm{MT}$ mice have a targeted disruption of the immunoglobulin $\mu$ chain gene, resulting in lack of both mature B cells and secreted antibodies (22). B cell and antibody sufficient B6 (WT) mice were used as controls. All mice received BALB/c allografts, and CAV was analyzed at 100 to 110 days after transplantation. Histological examination of allografts in WT recipients revealed arteritis with perivascular inflammation and intimal hyperplasia causing obliterative vasculopathy, characteristic of CAV (Supplemental Figure 1A; supplemental material available online with this article; doi:10.1172/JCI70084DS1). Despite the complete absence of antibodies, AID/ $\mu$ S KO mice developed CAV lesions similar to those found in WT recipients (Supplemental Figure 1A). In contrast, allografts in $\mu \mathrm{MT}$ recipients, which lack both B cells and antibodies, displayed minimal CAV (Supplemental Figure 1A). Morphometric quantitation represented as percentage of vessels affected by CAV in each allograft (Figure $1 \mathrm{~A}$ ) and percentage of luminal occlusion in each vessel (Figure 1B) confirmed that CAV was attenuated in $\mu \mathrm{MT}$ but not in $\mathrm{AID} / \mu \mathrm{S} \mathrm{KO}$ recipients. Importantly, CAV was restored in $\mu \mathrm{MT}$ recipients upon adoptive trans- 
$\mathbf{A}$

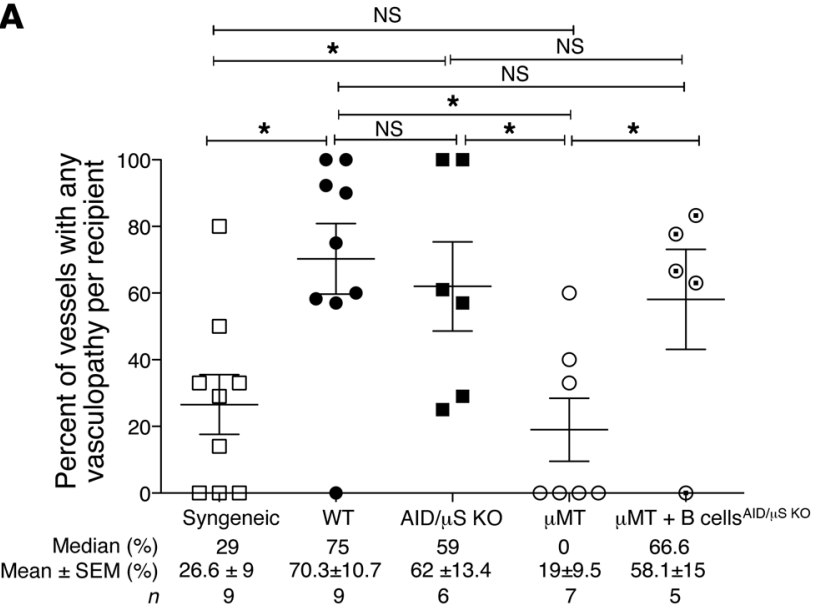

B

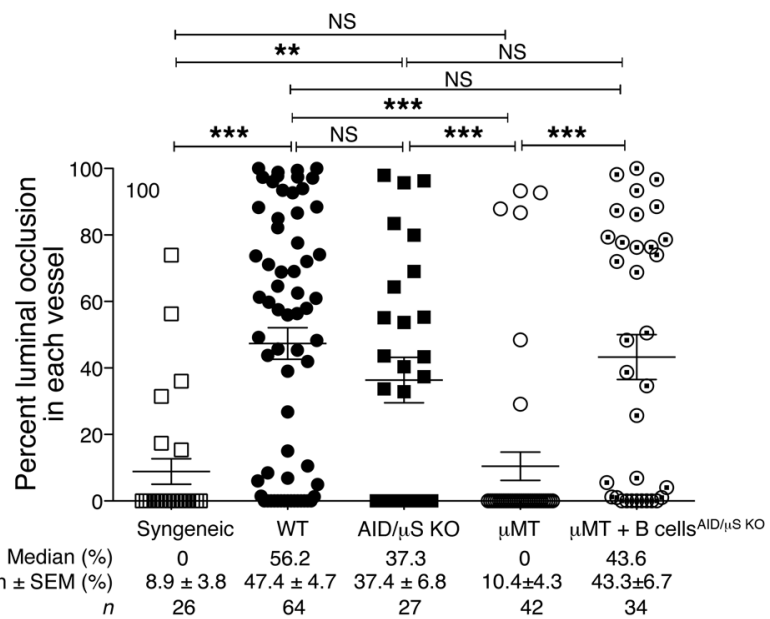

C

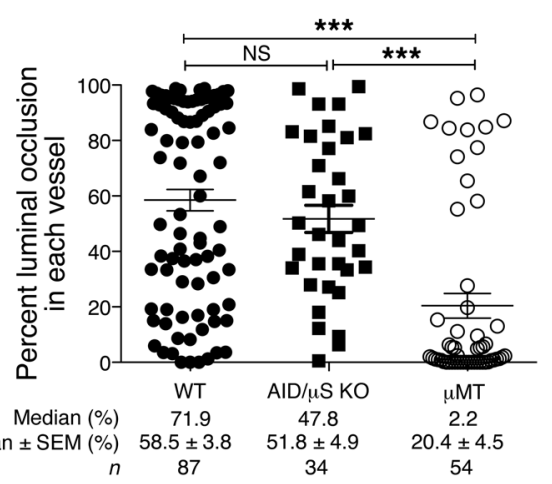

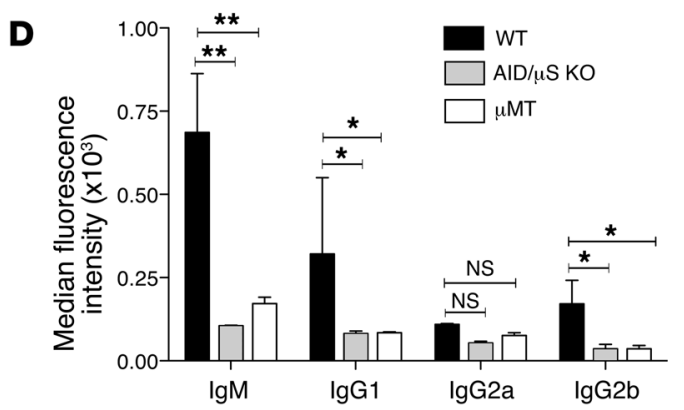

Figure 1

$B$ cells are sufficient for CAV in the absence of antibodies. WT, AID/ $\mu$ S KO, $\mu \mathrm{MT}$, and $\mu \mathrm{MT}+\mathrm{B}$ cells $\mathrm{AID} / \mu \mathrm{S}$ KO recipients were transplanted with BALB/C hearts and treated with costimulation blockade $(0.25 \mathrm{mg}$, CTLA4lg and anti-CD40L, on days $2,4,6$, and 8$)$. $\mu \mathrm{MT}+\mathrm{B}$ cells ${ }^{\mathrm{AID} / \mu \mathrm{S}} \mathrm{KO}$ recipients were $\mu \mathrm{MT}$ mice that received naive AID/uS KO B cells $\left(2 \times 10^{7}, 2\right.$ to 4 days before transplantation). Allografts were beating and contracting at harvest (100-110 days). (A and B) Morphometric quantitation of vasculopathy in each recipient (A), and luminal occlusion in each vessel (B) (mean \pm SEM; $n=26-64$ vessels, 5-9 mice per group). (C) Morphometric quantitation of luminal occlusion in each vessel in Bm12 heart allografts from untreated recipients (at 90-100 days, mean \pm SEM; $n=34-87$ vessels, $5-10$ mice per group). (D) Median fluorescence intensity of BALB/c-reactive antibodies in sera of BALB/c heart recipients at harvest (1:4 dilution, mean $\pm \mathrm{SD} ; n=4-6$ mice per group). ${ }^{*} P<0.05 ;{ }^{* *} P<0.005 ;{ }^{* \star *} P<0.0005$.

fer of B cells that do not produce antibodies (naive B cells from $\mathrm{AID} / \mu \mathrm{S} \mathrm{KO}, \mu \mathrm{MT}+\mathrm{B}$ cells ${ }^{\mathrm{AID} / \mu \mathrm{S} \text { KO }}$ group) (Figure $1, \mathrm{~A}$ and $\mathrm{B}$ ). Similarly, untreated WT and AID/ $\mu$ S KO recipients of Bm12 heart allografts developed significant $\mathrm{CAV}$, whereas $\mu \mathrm{MT}$ recipients did not (Figure 1C). Neither circulating donor-reactive antibodies nor IgG deposits within allograft vessels were observed in AID/ $\mu \mathrm{S} \mathrm{KO}$ recipients (Figure 1D and Supplemental Figure 1B), confirming that CAV in these mice indeed occurred in the absence of antibodies. These results demonstrate that $\mathrm{B}$ cells are sufficient and antibodies are not necessary for development of CAV and suggest that B cells could contribute to CAV by mechanisms other than antibody production.

Alloreactive $T$ cell responses are diminished in the absence of $B$ cells. To investigate whether B cells contribute to CAV by influencing T cell responses, $\mathrm{T}$ cell activation and cytokine production were examined at the time of graft harvest. As shown in Figure 2A, IFN- $\gamma$ and TNF- $\alpha$ production by $\mathrm{CD}^{+}$and $\mathrm{CD}^{+} \mathrm{T}$ cells in response to donor splenocytes was intact in $\mathrm{AID} / \mu \mathrm{S} \mathrm{KO}$ recipients and $\mathrm{T}$ cell activation, measured by CD44, CD62L, and CD69 expression, was enhanced, especially in the $\mathrm{CD}^{+}$compartment. In con- trast, cytokine production by both $\mathrm{CD}^{+}$and $\mathrm{CD}^{+} \mathrm{T}$ cells, measured as percentage and absolute number of cytokine-producing $\mathrm{T}$ cells, was significantly reduced in $\mu \mathrm{MT}$ recipients (Figure $2 \mathrm{~A}$ ), with evidence of diminished activation of $\mathrm{CD} 4^{+} \mathrm{T}$ cells (decreased CD44 expression). Moreover, $\mathrm{T}$ cell infiltration of graft vessels was conspicuous in AID/ $\mu \mathrm{S} \mathrm{KO}$ and $\mathrm{WT}$ recipients, but was nearly absent in $\mu \mathrm{MT}$ recipients (Figure $2 \mathrm{~B}$ ). Because B cells can affect $\mathrm{T}$ cell homeostasis by influencing splenic lymphoid architecture (17-19), total T cells in recipients were also enumerated. We found that $\mathrm{CD} 4^{+} \mathrm{T}$ cell numbers were normal in $\mu \mathrm{MT}$ recipients, while $\mathrm{CD}^{+} \mathrm{T}$ cells were slightly diminished (Figure $2 \mathrm{C}$ ). AID/ $\mathrm{MS} \mathrm{KO}$ recipients, on the other hand, had a significant increase in $\mathrm{CD}^{+}$ $\mathrm{T}$ cell numbers (Figure $2 \mathrm{C}$ ). Together, these data indicate that alloreactive $\mathrm{T}$ cell responses are diminished in the absence of $\mathrm{B}$ cells. This function of B cells could be mediated indirectly by supporting splenic lymphoid architecture and/or by direct action of B cells on T cells (e.g., antigen presentation).

Cognate and noncognate functions of $B$ cells contribute to $C A V$. Splenic architecture in $\mu \mathrm{MT}$ recipients was disrupted without marginal zones and diminished $\mathrm{T}$ cell areas (Supplemental Figure 
A
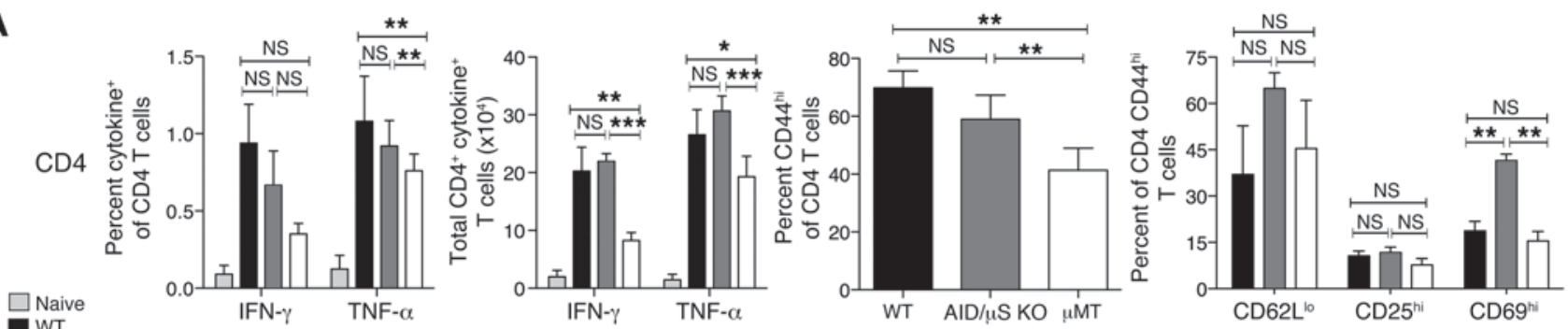

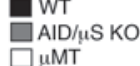
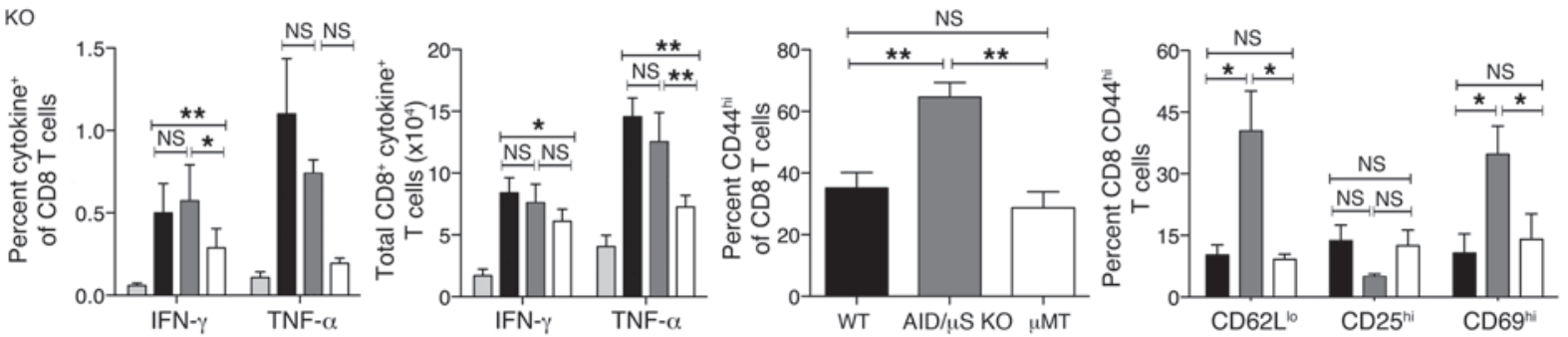

B

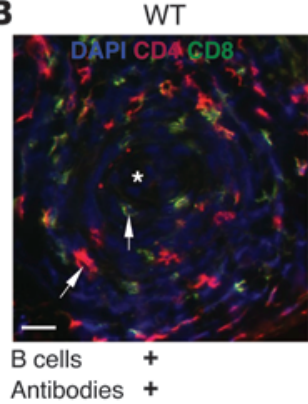

$\mathrm{AID} / \mathrm{uS} \mathrm{KO}$

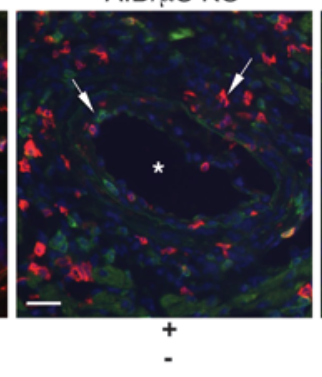

$\mu \mathrm{MT}$

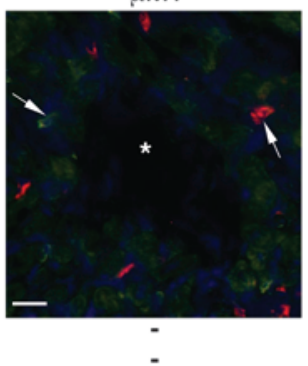

C

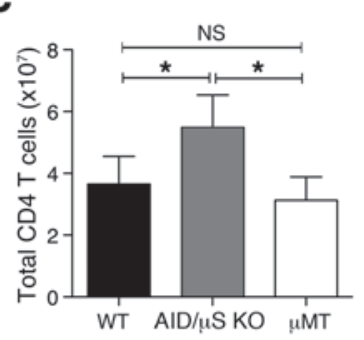

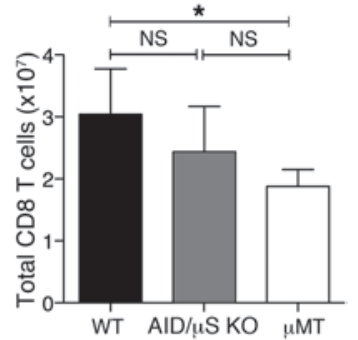

Figure 2

Alloreactive T cell responses are diminished in the absence of B cells. (A) Spleen, $L N$, and BM cells were harvested from WT, AID/uS KO and $\mu M T$ recipients of BALB/c hearts treated with costimulation blockade for assessment of $T$ cell activation and cytokine production (at allograft harvest for CAV, 100-110 days after transplantation). Harvested cells were stimulated with BALB/c splenocytes for 6 hours and IFN- $\gamma^{+}$and TNF- $\alpha^{+}$cells within the $\mathrm{H}-2^{\mathrm{d}}$ negative recipient T cells were assessed by intracellular cytokine staining. Percentage and total numbers of IFN- $\gamma^{+}$and TNF- $\alpha^{+}, \mathrm{CD}^{+}$and $C D 8^{+} T$ cells in allograft recipients and naive mice are shown. Percentage of $C D 44^{\text {hi }} T$ cells, and CD62 $L^{10}, C D 25^{\text {hi }}$, and $C D 6 g^{\text {hi }}$ cells within $C D 44^{\text {hi }}$ T cells in allograft recipients are shown. (B) Representative images of immunofluorescence staining in cryosections of heart allografts from recipients showing CD4+ (red), $\mathrm{CD} 8^{+}$(green), and DAPI (blue). Arrows point to $\mathrm{CD} 4^{+}$or $\mathrm{CD} 8^{+} \mathrm{T}$ cells. Original magnification, $\times 20$. Scale bars: $150 \mu \mathrm{m}$. (C) Total T cell numbers were enumerated in spleen, $\mathrm{LN}$, and BM cells from allograft recipients at the time of harvest. Data shown are representative of 2 independent experiments (mean \pm SD; $n=4-6$ mice per group). ${ }^{*} P<0.05 ;{ }^{* \star} P<0.005 ;{ }^{* \star *} P<0.0005$.

2A) that could have accounted for attenuated alloreactive $T$ cell responses and $\mathrm{CAV}$ in these mice. To test this possibility, we utilized $\mathrm{Ig}^{\mathrm{HEL}} \mathrm{B}$ cell receptor (BCR) transgenic mice wherein $\mathrm{B}$ cells are specific for hen egg lysozyme (HEL) (23) but do not recognize $\mathrm{BALB} / \mathrm{c}$ alloantigens, and thus provide only noncognate (not dependent on recognition of antigen by B cells) functions in our transplant model. CAV was restored in $\mathrm{Ig}^{\mathrm{HEL}}$ recipients but only partially when compared with WT recipients (Figure $3 \mathrm{~A}$ ), despite preserved splenic architecture (Supplemental Figure $2 \mathrm{~B}$ ), suggesting that noncognate $\mathrm{B}$ cell functions alone were not sufficient. B cells in Ig ${ }^{\mathrm{HEL}}$ recipients could be contributing to CAV not only by supporting lymphoid architecture but also by taking up alloantigen, albeit inefficiently, via non-BCR (noncognate) mechanisms and presenting it to T cells. It's also possible that there is a minor contribution from the few nonHEL-specific B cells present in $\mathrm{Ig}^{\mathrm{HEL}}$ recipients that could be alloreactive and present alloantigen taken up via the cognate $B C R$ to $\mathrm{T}$ cells. In contrast, adoptive transfer of polyclonal AID $/ \mu \mathrm{S}$
KO B cells, which provided cognate (dependent on antigen recognition by $\mathrm{B}$ cells) and noncognate functions but not antibodies, into $\mu \mathrm{MT}$ recipients $\left(\mu \mathrm{MT}+\mathrm{B}\right.$ cells $\left.\mathrm{sID}^{\mathrm{ADS}} \mathrm{KO}\right)$ not only improved splenic architecture (Supplemental Figure 2C), but also restored CAV to the full extent seen in WT recipients (Figure $1, \mathrm{~A}$ and B). $\mu \mathrm{MT}+\mathrm{B}$ cells $\mathrm{sID}^{\mathrm{AIS}} \mathrm{KO}$ recipients also showed greater $\mathrm{CD} 4^{+}$and $\mathrm{CD}^{+} \mathrm{T}$ cell IFN- $\gamma$ response to donor splenocytes than $\mathrm{Ig}^{\mathrm{HEL}}$ recipients (Figure $3 \mathrm{~B}$ ), suggesting that both cognate and noncognate $\mathrm{B}$ cell functions contributed to the alloreactive $\mathrm{T}$ cell response in these recipients.

To further examine the role of $\mathrm{B}$ cells as antigen-presenting cells in the pathogenesis of CAV, we transplanted $\mathrm{BALB} / \mathrm{c}$ hearts into syngeneic $\mathrm{BM}$ chimeras wherein $\mathrm{B}$ cells were present but lacked MHC I and II expression ( $\mu \mathrm{MT}+\mathrm{MHC}-\mathrm{KO} \rightarrow \mu \mathrm{MT}$ ) (Supplemental Figure $3 \mathrm{~A}$ ). In these chimeras, $\mathrm{B}$ cells are unable to present antigen to $\mathrm{T}$ cells while non- $\mathrm{B}$ cell antigen-presenting cells remain intact. Chimeras containing B cells that can present antigen to $\mathrm{T}$ cells $(\mu \mathrm{MT}+\mathrm{WT} \rightarrow \mu \mathrm{MT})$ and chimeras that completely lack 
A

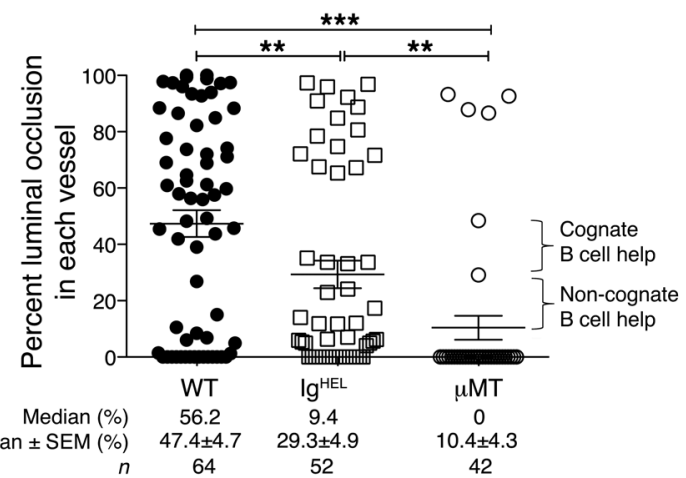

C

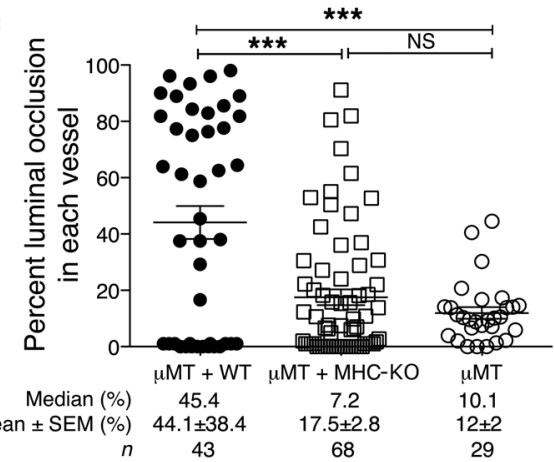

B
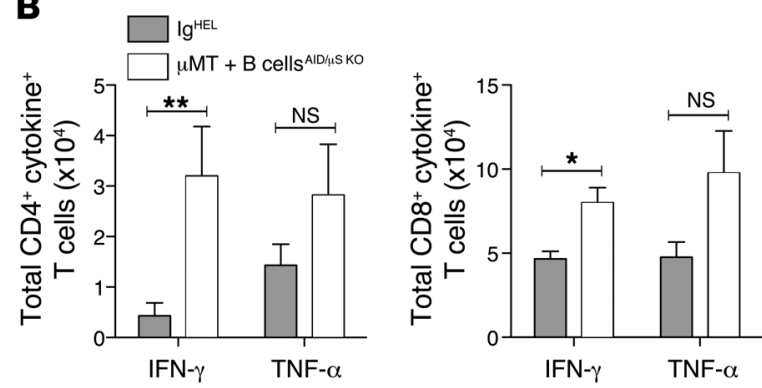

D

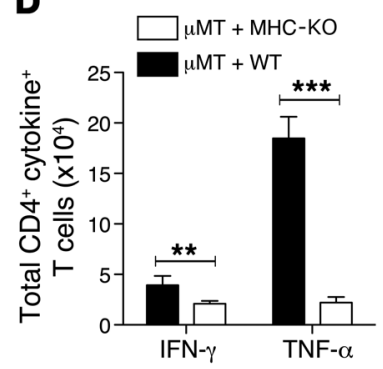

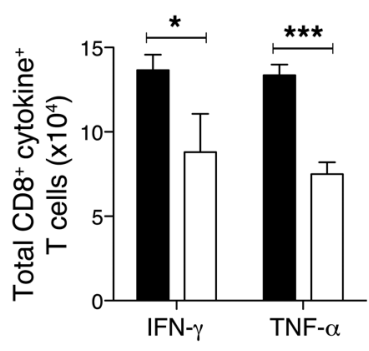

Figure 3

Cognate and noncognate functions of B cells contribute to CAV. All recipients were transplanted with BALB/c hearts, treated with costimulation blockade, and harvested between 90 and 100 days. Recipient spleen, LN, and BM cells were stimulated with BALB/c splenocytes for 24 hours, and the total number of IFN- $\gamma^{+}$and TNF- $\alpha^{+}$cells within $\mathrm{H}-2^{\mathrm{d}}$-negative recipient T cells were enumerated. (A) Morphometric quantitation of CAV in heart allografts from Ig ${ }^{\mathrm{HEL}}$ recipients ( $\mu \mathrm{MT}$ and WT controls are the same as in Figure 1B). (B) Total IFN- $\gamma^{+}$and TNF- $\alpha^{+}$T cells in IgHEL and $\mu$ MT +

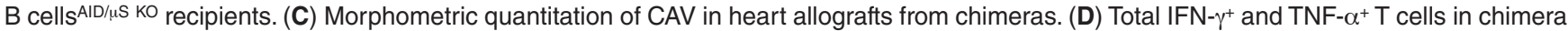
recipients. Results are mean \pm SEM ( $n=29-68$ vessels and 4-9 mice per group) (A and C) and mean \pm SD ( $n=4-6$ mice per group) (B and D) . ${ }^{\star} P<0.05 ;{ }^{* *} P<0.005 ;{ }^{* \star} P<0.0005$.

B cells $(\mu \mathrm{MT} \rightarrow \mu \mathrm{MT})$ were used as controls. Although splenic architecture was preserved (Supplemental Figure 3B), CAV was attenuated in $\mu \mathrm{MT}+\mathrm{MHC}-\mathrm{KO}$ chimeras compared with $\mu \mathrm{MT}+\mathrm{WT}$ chimeras and was equivalent to that observed in $\mu \mathrm{MT}$ chimeras (Figure 3C). Assessment of $\mathrm{CD}^{+}$and $\mathrm{CD}^{+} \mathrm{T}$ cell cytokines in response to donor splenocytes in chimeric mice showed a significant reduction in IFN- $\gamma$ and TNF- $\alpha$ production in $\mu \mathrm{MT}+\mathrm{MHC}-\mathrm{KO}$ chimeras (Figure 3D). Finally, examination of allografts revealed vascular infiltration with $\mathrm{CD}^{+}$and $\mathrm{CD}^{+} \mathrm{T}$ cells in $\mu \mathrm{MT}+\mathrm{WT}$ chimeras, but not in $\mu \mathrm{MT}+\mathrm{MHC}-\mathrm{KO}$ or $\mu \mathrm{MT}$ chimeras (Supplemental Figure 4). These findings indicate that cognate antigen presentation by B cells plays an important role in the pathogenesis of CAV by enhancing alloreactive $T$ cell responses.

Our findings provide what we believe are new insights into the pathogenesis of chronic allograft rejection. We established that CAV could occur in the complete absence of antibodies, but not in the absence of both $\mathrm{B}$ cells and antibodies. We presented evidence that $B$ cells drive the pathogenesis of CAV by supporting $\mathrm{T}$ cell responses through both antigen presentation and maintenance of splenic lymphoid architecture. Our findings could explain why many patients develop chronic rejection in the absence of detectable alloantibodies $(3,8)$. Indeed, B cell depletion abrogates CAV in primate heterotopic heart transplants, inhibits chronic rejection of murine kidney allografts, and improves survival of islet transplants in primates without necessarily eliminating donor-reactive antibodies (24-26). Similarly, B cell depletion induces disease remission in autoimmune diseases such as lupus despite persistence of autoantibodies (27). Although antibody secretion is unquestionably a key function of B cells in alloimmunity, our data underscore that B cells also contribute to CAV by enhancing $\mathrm{T}$ cell responses. B cell populations with regulatory functions that inhibit $\mathrm{T}$ cells and prolong allograft survival have also been identified (28), and further understanding of which specific B cell populations contribute to human chronic rejection would pave the way toward targeted therapy in the clinic.

\section{Methods}

Further information is available in Supplemental Methods.

Statistics. Two-tailed Student's $t$ test was used to assess statistical differences between groups using Graphpad Prism 5 software, and differences with $P<0.05$ were considered significant.

Study approval. All animal studies were approved by the University of Pittsburgh IACUC (protocol no. 12070595; PHS assurance no. A3187-01).

\section{Acknowledgments}

This work was supported by grants NIH AI079177 (to G. Chalasani) and ROTRF 978906253 (to G. Chalasani), an American Heart Association postdoctoral fellowship (to Y-.H. Ng), an American Society of Transplantation postdoctoral fellowship (to K.A. Sheriff), 
a Thomas E. Starzl postdoctoral fellowship (to K. Jiang), and a University of Pittsburgh Department of Medicine Junior Scholar Award (to G. Chalasani). NIH AI068056 (to F.E. Lund) funds were used to develop, characterize and maintain AID/ $\mu \mathrm{S}$ KO mice. We thank Fadi Lakkis and David Rothstein for valuable input and critical comments.

1. Lodhi SA, Lamb KE, Meier-Kriesche HU. Solid organ allograft survival improvement in the United States: the long-term does not mirror the dramatic short-term success. Am J Transplant. 2011;11(6):1226-1235

2. Radio S, Wood S, Wilson J, Lin H, Winters G, McManus B. Allograft vascular disease: comparison of heart and other grafted organs. Transplant Proc. 1996;28(1):496-499.

3. Mauiyyedi S, et al. Chronic humoral rejection: identification of antibody-mediated chronic renal allograft rejection by $\mathrm{C} 4 \mathrm{~d}$ deposits in peritubular capillaries. J Am Soc Nephrol. 2001;12(3):574-582.

4. Terasaki PI, Cai J. Human leukocyte antigen antibodies and chronic rejection: from association to causation. Transplantation. 2008;86(3):377-383

5. Nath DS, et al. Donor-specific antibodies to human leukocyte antigens are associated with and precede antibodies to major histocompatibility complex class I-related chain A in antibody-mediated rejection and cardiac allograft vasculopathy after human cardiac transplantation. Hum Immunol. 2010;71(12):1191-1196.

6. Russell PS, Chase CM, Winn HJ, Colvin RB. Coronary atherosclerosis in transplanted mouse hearts II. Importance of humoral immunity. J Immunol. 1994; 152(10):5135-5141.

7. Uehara S, Chase CM, Cornell LD, Madsen JC, Russell PS, Colvin RB. Chronic cardiac transplant arteriopathy in mice: relationship of alloantibody, C4d deposition and neointimal fibrosis. Am J Transplant. 2007;7(1):57-65

8. Sis B, et al. Transplant glomerulopathy, late antibody-mediated rejection and the ABCD tetrad in kidney allograft biopsies for cause. Am J Transplant. 2007;7(7):1743-1752
9. Uehara S, et al. NK cells can trigger allograft vasculopathy: the role of hybrid resistance in solid organ allografts. J Immunol. 2005;175(5):3424-3430.

10. Kitchens WH, et al. Macrophage depletion suppresses cardiac allograft vasculopathy in mice. Am J Transplant. 2007;7(12):2675-2682.

11. Suzuki J, et al. Tumor necrosis factor receptor-1 and -2 double deficiency reduces graft arterial disease in murine cardiac allografts. Am J Transplant. 2003;3(8):968-976

12 . Wang $\mathrm{Y}$, et al. Interferon- $\gamma$ plays a nonredundant role in mediating $\mathrm{T}$ cell-dependent outward vascular remodeling of allogeneic human coronary arteries. FASEB J. 2004;18(3):606-608.

13. Shi $\mathrm{C}$, et al. Immunologic basis of transplantassociated arteriosclerosis. Proc Natl Acad Sci U S A. 1996;93(9):4051-4056.

14. Noorchashm H, et al. B cell-mediated antigen presentation is required for the pathogenesis of acute cardiac allograft rejection. J Immunol. 2006;177(11):7715-7722.

15. Ng YH, Oberbarnscheidt MH, Chandramoorthy HC, Hoffman R, Chalasani G. B cells help alloreactive T cells differentiate into memory T cells. Am J Transplant. 2010;10(9):1970-1980.

16. Lund FE, Randall TD. Effector and regulatory B cells: modulators of CD4(+) T cell immunity. Nat Rev Immunol. 2010;10(4):236-247.

17. Nolte MA, et al. B cells are crucial for both development and maintenance of the splenic marginal zone. J Immunol. 2004;172(6):3620-3627.

18. Ngo VN, Cornall RJ, Cyster JG. Splenic T zone development is B cell dependent. J Exp Med. 2001;194(11):1649-1660.

19. Fu YX, Huang G, Wang Y, Chaplin DD. B lymphocytes induce the formation of follicular dendritic fashion. J Exp Med. 1998;187(7):1009-1018.

20. Chalasani $G$, et al. The allograft defines the type of rejection (acute versus chronic) in the face of an established effector immune response. J Immunol. 2004;172(12):7813-7820.

21. Kumazaki K, Tirosh B, Maehr R, Boes M, Honjo T, Ploegh HL. AID $\mathrm{Al}^{-/} \mathrm{mus}^{-/}$mice are agammaglobulinemic and fail to maintain B220-CD138+ plasma cells. J Immunol. 2007;178(4):2192-2203.

22. Kitamura D, Roes J, Kuhn R, Rajewsky K. A B cell-deficient mouse by targeted disruption of the membrane exon of the immunoglobulin $\mu$ chain gene. Nature. 1991;350(6317):423-426.

23. Goodnow CC, et al. Altered immunoglobulin expression and functional silencing of self-reactive B lymphocytes in transgenic mice. Nature. 1988;334(6184):676-682

24. DiLillo DJ, et al. B lymphocytes differentially influence acute and chronic allograft rejection in mice. J Immunol. 2011;186(4):2643-2654.

25 . Kelishadi SS, et al. Preemptive CD20+ B cell depletion attenuates cardiac allograft vasculopathy in cyclosporine-treated monkeys. J Clin Invest. 2010;120(4):1275-1284.

26. Liu C, et al. B lymphocyte-directed immunotherapy promotes long-term islet allograft survival in nonhuman primates. Nat Med. 2007;13(11):1295-1298.

27. Looney RJ, et al. B cell depletion as a novel treatment for systemic lupus erythematosus: a phase I/II dose-escalation trial of rituximab. Arthritis Rheum. 2004;50(8):2580-2589.

28. Ding Q, et al. Regulatory B cells are identified by expression of TIM-1 and can be induced through TIM-1 ligation to promote tolerance in mice.J Clin Invest. 2011;121(9):3645-3656. 